\title{
MENINGKATKAN KEMAMPUAN GURU DALAM PEMBUATAN MEDIA PEMBELAJARAN MELALUI KEGIATAN WORKSHOP
}

\author{
(Penelitian Tindakan Pada Guru TK di Kecamatan Padalarang Kabupaten Bandung Barat Semester 1 Tahun \\ Pelajaran 2015-2016)
}

\author{
Muslihuddin \\ musdin09@yahoo.com
}

Widyaiswara LPMP Jawa Barat

\begin{abstract}
ABSTRAK
Penelitian ini dilatarbelakangi oleh kenyataan yang terjadi di lapangan bahwa rendahnya kemampuan guru dalam pembuatan media pembelajaran yang dapat memberi pengaruh terhadap kualitas sekolah. Oleh karena itu seorang widyaswara perlu mengembangkan sebuah kegiatan untuk meningkatkan kemampuan guru dalam pembuatan media pembelajaran. Salah satu kegiatan yang dicobakan melalui penelitian ini adalah workshop pembuatan media pembelajaran. Penelitian ini bertujuan untuk (1) Mengukur kemampuan guru dalam pembuatan media pembelajaran setelah diterapkan workshop. (2) Untuk mengetahui gambaran kemampuan guru dalam pembuatan dan menggunakan media pembelajaran sebelum dan setelah diterapkan workshop. (3) Meningkatkan kemampuan guru dalam pembuatan media pembelajaran melalui penerapan workshop. Hasil penelitian menunjukkan bahwa dengan diterapkannya workshop pembuatan media, kemampuan guru dalam membuat dan menggunakan media pembelajaran dapat ditingkatkan. Berdasarkan penelitian bahwa kemampuan guru dalam menggunakan media pembelajaran nilai rata-ratanya meningkat, peningkatan kemampuan guru dalam pembuatan media pembelajaran setelah diterapkan workshop bahan ajar pada siklus I mempunyai nilai rata-rata 70 dengan perbandingan $0 \%$ berada pada kategori baik, $70 \%$ berada pada kategori cukup dan 30\% berada pada kategori kurang. Pada siklus II, rata-rata kemampuan guru dalam menggunakan media pembelajaran meningkat menjadi 86,67, dengan perbandingan $100 \%$ berada pada kategori baik dan tidak ada yang berada pada pada kategori cukup dan kategori kurang. Dari uraian di atas peneliti menyimpulkan bahwa workshop pembuatan media dapat meningkatkan kemampuan guru dalam membuat dan menggunakan media pembelajaran, karena itu peneliti menyarankan agar workshop pengembangan media disosialisasikan dan digunakan sebagai alternatif untuk meningkatkan kemampuan guru dalam menggunakan media pembelajaran.
\end{abstract}

Kata-kata kunci : workshop pembuatan media, dan kemampuan guru, media pembelajaran TK.

\begin{abstract}
This study is motivated by the fact that teachers' inability in making instructional media gives effect to the school quality. Therefore, a Widyaswara instructor needs to develop an activity in order to improve teachers' ability in making instructional media. One of activities that is tested in this study is workshop of making instructional media. This study aims at (1) measuring teachers' ability in making and using instructional media after attending the workshop. (2) Knowing the description of teachers' ability in making and using instructional media before and after attending the workshop. (3) Improving teachers' ability in making instructional media through workshop activity. The results of the study show that through the implementation of workshop, teachers' ability in making and using instructional media is automatically improved. Based on the results, it is can be said that teachers who are able to use instructional media have better mean score. At the cycle 1, the improvement of teachers' ability in making instructional media after attending the workshop reached the mean score of 70 by the comparison of $100 \%$ is in the category of high, $70 \%$ is on the category of medium, and $30 \%$ is on the category of low. At the cycle II, teachers' ability in using instructional media reached the mean score of 86,67 by the comparison of $100 \%$ is on the category of high and there are no medium or low categories. Based on the explanation above, it can be concluded that the workshop of how to make appropriate instructional media can improve teachers' ability in making and using instructional media; therefore, the researcher suggests that the workshop of how to develop instructional media should be socialized and used as an alternative in improving teachers' ability in using instructional media.
\end{abstract}

Keywords: workshop of making media, teachers' ability, instructional media for kindergarten school 


\section{A. PENDAHULUAN}

Pendidikan memegang peran yang sangat penting dalam proses peningkatan kualitas sumber daya manusia. Peningkatan kualitas pendidikan merupakan suatu proses yang terintegrasi dengan proses peningkatan kualitas sumber daya manusia itu sendiri. Mulyasa (2007: 3) menjelaskan bahwa pendidikan adalah salah satu wahana yang berperan untuk meningkatkan kualitas SDM, sehingga kualitas pendidikan harus selalu ditingkatkan. Menyadari pentingnya proses peningkatan kualitas sumber daya manusia melalui pendidikan, maka pemerintah bersama kalangan swasta sama-sama telah dan terus berupaya mewujudkan amanat tersebut melalui berbagai usaha pembangunan pendidikan yang lebih berkualitas antara lain melalui pengembangan dan perbaikan kurikulum dan sistem evaluasi, perbaikan sarana pendidikan, pengembangan dan pengadaan materi ajar, serta pelatihan bagi guru dan tenaga kependidikan lainnya, tetapi pada kenyataannya upaya pemerintah tersebut belum cukup berarti dalam meningkatkan kuailtas pendidikan.

Sebagaimana tercantum dalam Pasal 19 ayat (3) PP RI No 19 Tahun 2005, dijelaskan bahwa setiap satuan pendidikan melakukan perencanaan proses pembelajaran, pelaksanaan proses pembelajaran, penilaianhasil pembelajaran, dan pengawasan proses pembelajara nuntuk terlaksananya proses pembelajaran yang efektif danefisien. Disisi lain, keberhasilan pelaksanaan proses pendidikan di tingkat satuan pendidikan merupakan hal yang berhubungan erat dengan guru sebagai pihak yang secara langsung melaksanakan proses pendidikan di sekolah. Arti penting peran guru terhadap kualitas output pendidikan ini tersirat dalam Undang-Undang Nomor 14 Tahun 2005 tentang Guru dan Dosen pada Pasal 4 dinyatakan, bahwa kedudukan guru sebagai tenaga profesional berfungsi untuk meningkatkan martabat dan peran guru sebagai agen pembelajaran, yang sekaligus berfungsi untuk meningkatkan mutu pendidikan nasional. Hal ini menunjukkan bahwa guru memiliki peran yang penting dalam pelaksanaan pendidikan di tingkat satuan pendidikan, sehingga diarahkan menjadi tenaga profesional bertumpu pada tujuan meningkatnya kualitas output pendidikan. kualitas pendidik di jenjang anak usia dini, harus senantiasa dioptimalkan pelayannnya yang berorientasi pada peningkatan kualitas. Pendidikan Anak Usia Dini sebagai jenjang pendidikan yang sangat penting dalam mempersiapkan anak untuk mengikuti pendidikan dasar. Oleh karena itu, pendidiknya perlu disiapkan secara baik dalam pelaksanaan diklat peningkatan mutu bagi pendidik PAUD. Fakta di lapangan, khususnya di kecamatan Padalarang Kabupaten Bandung Barat, ditemukan masih rendahya kepercayaan dan kesadaran masyarakat akan pentingnya PAUD dan masyarakat masih memandang remeh pembelajaran yang diberikan di PAUD (sekedar bernyanyi \& bermain-main saja), serta proses pembelajaran yang belum sepenuhnya memenuhi standar dan cenderung berorientasi pada pengajaran baca-tulis-hitung (calistung) sehingga menyebabkan rendahnya penghargaan yang diberikan pada pendidik AUD. Dua masalah pokok inilah yang menyebabkan layanan PAUD sulit menyebar lebih luas sedangkan layanan PAUD yang sudah ada susah untuk meningkatkan mutu layanan karena kesulitan untuk mendapatkan calon pendidik-pendidik yang profesional. Sehubungan dengan hal tesebut, Pendidik PAUD dituntut dapat memenuhi kebutuhan dan perkembangan masyarakat.

Oleh karena itu penyelenggaraan workshop dalam rangka memberikan keterampilan dan kemampuan guru dalam membuat media pembelajaran diharapkan dapat memberikan stimulus, untuk meningkatakan kualitas layanan pendidikan anak usia dini. Sehingga jika kualitas pembelajaran meningkat, maka kepercayaan dari orang tua untuk pendidikan anak usia dini akan meningkat pula.

Berdasarkan rumusan masalah kemudian tujuan penelitian ini pun disusun yakni: (1) Mendapatkan deskripsi nyata mengenai kemampuan guru dalam pembuatan media pembelajaran dengan dilaksanakannya workshop; (2) Untuk mengetahui proses peningkatan kemampuan guru dalam pembuatan media pembelajaran sebelum dan sesudah diterapkan workshop; (3) Untuk mengetahui besarnya peningkatan kemampuan guru dalam pembuatan media pembelajaran dengan dilaksanakannya workshop.

Penelitian ini diharapkan mampu memberikan kontribusi bagi perbaikan pembelajaran, adapun manfaat lainnya adalah sebagai berikut: (1) Bagi anak, mampu meningkatkan hasil belajar anak dan proses belajar mengajar menjadi lebih bermakna; (2) Bagi Guru, meningkatkan kemampuan guru dalam proses pembelajaran sehingga lebih profesional; (3) Bagi Sekolah, memberikan konstribusi dalam mengembangkan kualitas pembelajarandan meningkatkan kemajuan sekolah. 


\section{B. KAJIAN TEORI DAN METODE}

\section{Kajian Teori}

Jika ditinjau dari asal katanya, workshop merupakan frasa kata yang berasal dari bahasa Inggris yaitu work (yang memiliki arti kerja ataupun pekerjaan) dan shop (yang memiliki arti toko ataupun tempat menjual sesuatu). Jadi jika diartikan dari frasa kata nya, workshop dapat diartikan sebagai tempat berkumpulnya para pelaku aktivitas (berkaitan dengan bidang dunia kerja) tertentu yang mana dalam tempat ini, para pelaku melakukan interaksi saling menjual gagasan yang ditujukan untuk memecahkan suatu permasalahan tertentu.

Bila diartikan secara lengkap, maka workshop merupakan sebuah kegiatan yang sengaja diadakan sebagai tempat berkumpulnya orang-orang yang berasal dari latar belakang serumpun untuk memecahkan suatu permasalahan tertentu dengan jalan berdiskusi ataupun saling memberikan pendapat antar satu anggota dengan anggota lainnya

Lokakarya atau dalam bahasa Inggris disebut workshop dari Wikipedia bahasa Indonesia ensiklopedia bebas adalah suatu acara dimana beberapa orang berkumpul untuk memecahkan masalah tertentu dan mencari solusinya. Sebuah lokakarya atau workshop adalah pertemuan ilmiah yang kecil.

Sekelompok orang yang memiliki perhatian yang sama berkumpul bersama dibawah kepemimpinan beberapa orang ahli untuk menggali satu atau beberapa aspek khusus suatu topik. Sub-sub kelompok dibentuk untuk tujuan mendengarkan ceramah-ceramah, melihat demonstrasidemonstrasi, mendiskusikan berbagai aspek topik, mempelajari, menggerakan, mempraktekan, dan mengevaluasinya. Sebuah woorkshop biasanya terdiri dari Pimpinan workshop, anggota, dan Narasumber.

Dalam dunia pendidikan workshop adalah suatu device dalam in-service education, cara belajar sesuatu (a way learning) dengan menggunakan sharing of ideas, prosedure give and take " suatu sistem kerja yang sesuai dengan jiwa gotong royong".

Beberapa literatur menyebutkan bahwa workshop adalah pelatihan kerja, yang meliputi teori dan praktek dalam satu kegiatan terintegrasi. Workshop atau training jika diartikan dalam bahasa indonesia artinya pelatihan. Dengan definisi seperti itu sudah sangat jelas bahwa kita benar-benar akan praktek. Workshop atau training bersifat "learning by doing" dipandu oleh pelatih dan peserta benarbenar prakek apa yang diajarkan.

Kegiatan workshop atau lokakarya merupakan kegiatan yang sudah sering dilakukan oleh berbagai kalangan, dan meliputi berbagai bidang. Kegiatan workshop memang bermanfaat, sehingga banyak pihak yang menyelenggarakan kegiatan tersebut.

Tujuan workshop adalah untuk memperoleh informasi melalui pengalaman langsung dan saling menyampaikan informasi. Selain itu workshop juga bertujuan untuk mengembangkan pengetahuan, pemahaman, dan keterampilan para target atau sasaran. Objeknya seorang atau sekelompok orang. Sasarannya untuk memberikan pemahaman, pengetahuan, dan keterampilan kepada target sesuai kebutuhan masing-masing. Prosesnya mempelajari dan mempraktekkan apa yang menjadi topik sesuai dengan prosedur sehingga menjadi kebiasaan. Hasilnya bisa segera terlihat karena memang langsung praktek. Sehingga ada perubahan yang memungkinkan tercipta setelah mengikuti acara training tersebut.

Dalam prakteknya workshop mempunyai ciri dan prosedur yang dapat ditinjau dari beberapa aspek. Ciri dan Prosedur workshop tersebut hanya digunakan sebagai suatu cara untuk memudahkan dalam pelaksanaan dan penyelenggaraan workshop.

Beberapa ciri-ciri workshop antara lain:

a. Masalah yang dibahas bersifat "life centered" dan muncul dari peserta sendiri

b. Cara yang digunakan adalah metode pemecahan masalah "musyawarah dan penyelidikan"

c. Mennggunakan resource materials yang memberi bantuan yang besar sekali dalam mencapai hasil yang sebaik-baiknya.

Adapun Prosedur pelakanaan workshop meliputi beberapa hal, antara lain:

a. Merumuskan tujuan workshop (output yang akan dicapai)

b. Merumuskan pokok-pokok masalah yang akan dibahas secara terperinci

c. Menentukan prosedur pemecahan masalah.

Dalam menggolongkan dan mempelajari berbagai disiplin ilmu masih banyak yang belum mengetahui jenis-jenisnya, bertitik tolak dari 
masalah tersebut maka perlu dikemukakan mengenai jenis-jenis workshop berdasarkan berbagai aspek dan kebutuhan. Berikut ini jenisjenis workshop berdasarkan kebutuhan penyelenggaraan yang ditentukan oleh lembaga/ organisasi yang melaksanakan dan sifat kerjanya.

Pengelompokkan workshop yang didasarkan pada aspek ini disesuaikan/tergantung pada lembaga atau organisasi yang menyelenggarakan. Misalnya workshop tentang implementasi internal kontrol pada perusahaan. Konsep pengendalian intern mutakhir menawarkan alternatif cara pandang dan mekanisme sistem pengendalian yang tidak hanya adafttif dan akomodatif, akan tetapi juga memberikan stimulasi bagi berkembangnya inisiatif dan kreativitas pegawai dan manajemen perusahaan. Dengan konsep pengendalian intern yang mutakhir ini auditor internal diharapkan dapat lebih meningkakan peran konsultatif dan katalis sebagai pelayanan terhadap kepentingan perusahaan.

Tujuan mengikuti pelatihan ini peserta diharapkan dapat:

1) Memahami konsep pengendalian intern yang sesuai dengan kebutuhan manajemen dan pegawai untuk mengembang inisiatif dan kreativitas dalam bekerja

2) Mengembangkan dan mengimplementasikan konsep pengendalian intern yang sesuai dengan budaya kerja yang berdasarkan empowermant process.

Adapun materi yang diberikan adalah:

- Internal Control Overview.

- Control Environtment and Assessment Control

- Risk Identification

- Risk Measurement

- Control Aktivities

Contoh lain adalah workshop pendidikan. Ruang lingkup yang dibahas dalam workshop ini adalah seputar problematika pendidikan. Misalnya workshop sertifikasi guru dalam jabatan. Dalam workshshop ini akan dibahas komponen-komponen dalam sertifikasi yang meliputi:

1) Kualifikasi Akademik

2) Penndidikan dan pelatihan

3) Pengalaman Mengajar

4) Perencanaan dan Pelaksanaan Pembelajaran

5) Penilaian dari atasan dan pengawas

6) Prestasi Akademik

7) Karya Pengembangan Profesi
8) Keikutsertaan dalam forum ilmiah

9) Pengalaman Organisasi di bidang pendidikan dan sosial

10) Penghargaan yang Relevan dengan Bidang Pendidikan

Jenis workshop ditinjau dari aspek waktu pelaksanaannya dapat digolongkan menjadi 2, yaitu:

1) Workshop Beruntun

Yang dimaksud dengan workshop beruntun adalah worksop yang dilakukan dalam dekade tertentu secara terus menerus atau tidak terputus. Kebanyakan worksho ini 3 hari berturut-turut.

2) Workshop berkala

Yang dimaksud dengsn workshop berkala ialah: workshop yang dilakukan dalam waktu yang memiliki jangka waktu tertentu. Misalnya workshop ini dilakukan dalam jangka waktu mingguan atau bulanan.

Jenis workshop ditinjau dari sifatnya dapat digolongkan menjadi 2, yaitu:

1) Worksop yang bersifat mengikat

Workshop yang diadakan oleh suatu organisasi atau orang-orang tertentu yang membicarakan masalah-masalah program kerja yang sudah dilaksanakan dan menentukan langkah-langkah lanjutan yang hasilnya mengikat peserta workshop. Misalnya workshop tentang Standarisasi ISO atau GMP disuatu perusaaan.

2) Worksop yang bersifat tidak mengikat Workshop yang diadakan oleh orang-orang tertentu yang membicarakan masalah-masalah faktual yang muncul di masyarakat utuk memperoleh pemecahannya dan hasilnya tidak mengikat peserta workshop. Misalnya workshop tentang penurunan emisi gas $\mathrm{CO} 2$ pada perumahan dan pemukiman perkotaan sebagai antisipasi pemanasan global.

Media pembelajaran merupakan salah satu komponen pembelajaran yang mempunyai peranan penting dalam Kegiatan Belajar Mengajar. Pemanfaatan media seharusnya merupakan bagian yang harus mendapat perhatian guru/fasilitator dalam setiap kegiatan pembelajaran. Oleh karena itu guru/ fasilitator perlu mempelajari bagaimana menetapkan media pembelajaran agar dapat mengefektifkan pencapaian tujuan pembelajaran dalam proses belajar mengajar.

Pada kenyataannya media pembelajaran masih sering terabaikan dengan berbagai alasan, antara 
lain: terbatasnya waktu untuk membuat persiapan mengajar, sulit mencari media yang tepat, tidak tersedianya biaya, dan lain-lain. Hal ini sebenarnya tidak perlu terjadi jika setiap guru/ fasilitator telah mempunyai pengetahuan dan ketrampilan mengenai media pembelajaran.

Kata media merupakan bentuk jamak dari 'Medium', yang secara harfiah berarti perantara atau pengantar. Beberapa ahli memberikan definisi tentang media pembelajaran. Schramm (1977) mengemukakan bahwa media pembelajaran adalah teknologi pembawa pesan yang dapat dimanfaatkan untuk keperluan pembelajaran. Secara khusus, kata tersebut dapat diartikan sebagai alat komunikasi yang digunakan untuk membawa informasi dari satu sumber kepada penerima. Dikaitkan dengan pembelajaran, media dimaknai sebagai alat komunikasi yang digunakan dalam proses pembelajaran untuk membawa informasi berupa materi ajar dari pengajar kepada peserta didik sehingga peserta didik menjadi lebih tertarik untuk mengikuti kegiatan pembelajaran.

Kata media berasal dari bahasa latin dan merupakan bentuk jamak dari kata medium yang secara harfiah berarti perantara atau pengantar. Media adalah segala sesuatu yang dapat digunakan untuk menyalurkan pesan dari pengirim ke penerima sehingga dapat merangsang pikiran, perasaan, perhatian, dan minat serta perhatian siswa sedemikian rupa sehingga proses belajar terjadi (Sadiman, 2002: 6).

Latuheru (1988:14), menyatakan bahwa media pembelajaran adalah bahan, alat, atau teknik yang digunakan dalam kegiatan belajar mengajar dengan maksud agar proses interaksi komunikasi edukasi antara guru dan siswa dapat berlangsung secara tepat guna dan berdaya guna.Berdasarkan definisi tersebut, media pembelajaran memiliki manfaat yang besar dalam memudahkan siswa mempelajari materi pelajaran. Media pembelajaran yang digunakan harus dapat menarik perhatian siswa pada kegiatan belajar mengajar dan lebih merangsang kegiatan belajar siswa.

Satu hal yang perlu diingat bahwa peranan media tidak akan terlihat apabila penggunaannya tidak sejalan dengan isi dan tujuan pembelajaran yang telah dirumuskan. Secanggih apa pun media tersebut, tidak dapat dikatakan menunjang pembelajaran apabila keberadaannya menyimpang dari isi dan tujuan pembelajarannya. Perkembangan ilmu pengetahuan dan teknologi semakin mendorong upaya-upaya pembaharuan dalam pemanfaatan hasil-hasil teknologi dalam proses belajar mengajar. Para guru dituntut agar mampu menggunakan alat-alat yang dapat disediakan oleh sekolah, dan tidak tertutup kemungkinan bahwa alat-alat tersebut sesuai dengan perkembangan dan tuntutan zaman. Guru sekurang-kurangnya dapat menggunakan alat yang murah dan bersahaja tetapi merupakan keharusan dalam upaya mencapai tujuan pengajaran yang diharapkan.

Disamping mampu menggunakan alat-alat yang tersedia, guru juga dituntut untuk dapat mengembangkan alat-alat yang tersedia, guru juga dituntut untuk dapat mengembangkan keterampilan membuat media pengajaran yang akan digunakannya apabila media tersebut belum tersedia. Untuk itu guru harus memiliki pengetahuan yang cukup tentang media pengajaran, yang meliputi (Hamalik, 1994 : 6) :

- Media sebagai alat komunikasi guna lebih mengefektifkan proses belajar mengajar;

- Fungsi media dalam rangka mencapai tujuan pendidikan;

- Seluk-beluk proses belajar;

- Hubungan antara metode mengajar dan media pendidikan;

- Nilai atau manfaat media pendidikan dalam pengajaran;

- Pemilihan dan penggunaan media pendidikan;

- Berbagai jenis alat dan teknik media pendidikan;

- Media pendidikan dalam setiap mata pelajaran;

- Usaha inovasi dalam media pendidikan.

Dengan demikian, dapat disimpulkan bahwa media adalah bagian yang tidak terpisahkan dari proses belajar mengajar demi tercapainya tujuan pendidikan pada umumnya dan tujuan pembelajaran di sekolah pada khususnya. Kata media berasal dari bahasa Latin medius yang secara harfiah berarti 'tengah', 'perantara' atau 'pengantar'. Dalam bahasa Arab, media adalah perantara atau pengantar pesan dari pengirim kepada penerima pesan.

Apabila media itu membawa pesan-pesan atau informasi yang bertujuan instruksional atau mengandung maksud-maksud pengajaran maka media itu disebut Media Pembelajaran.

Dalam suatu proses belajar mengajar, dua unsur yang sangat penting adalah metode mengajar dan media pengajaran. Kedua aspek ini saling berkaitan. Pemilihan salah satu metode mengajar tertentu akan mempengaruhi jenis media 
pengajaran yang sesuai, meskipun masih ada berbagai aspek lain yang harus diperhatikan dalam memilih media, antara lain tujuan pengajaran, jenis tugas dan respon yang diharapkan siswa kuasai setelah pengajaran berlangsung, dan konteks pembelajaran termasuk karakteristik siswa. Meskipun demikian, dapat dikatakan bahwa salah satu fungsi utama media pengajaran adalah sebagai alat bantu mengajar yang turut mempengaruhi iklim, kondisi, dan lingkungan belajar yang ditata dan diciptakan oleh guru.

Hamalik (1986) mengemukakan bahwa pemakaian media pengajaran dalam proses belajar mengajar dapat membangkitkan keinginan dan minat yang baru, membangkitkan motivasi dan rangsangan kegiatan belajar, dan bahkan membawa pengaruhpengaruh psikologis terhadap siswa.Secara umum, manfaat media dalam proses pembelajaran adalah memperlancar interaksi antara guru dengan siswa sehingga pembelajaran akan lebih efektif dan efisien. Tetapi secara lebh khusus ada beberapa manfaat media yang lebih rinci Kemp dan Dayton (1985) misalnya, mengidentifikasi beberapa manfaat media dalam pembelajaran yaitu :

- Penyampaian materi pelajaran dapat diseragamkan

- Proses pembelajaran menjadi lebih jelas dan menarik

- Proses pembelajaran menjadi lebih interaktif

- Efisiensi dalam waktu dan tenaga

- Meningkatkan kualitas hasil belajar siswa

- Media memungkinkan proses belajar dapat dilakukan dimana saja dan kapan saja

- Media dapat menumbuhkan sikap positif siswa terhadap materi dan proses belajar

- Merubah peran guru ke arah yang lebih positif dan produktif.

Selain beberapa manfaat media seperti yang dikemukakan oleh Kemp dan Dayton tersebut, tentu saja kita masih dapat menemukan banyak manfaat-manfaat praktis yang lain. Manfaat praktis media pembelajaran di dalam proses belajar mengajar sebagai berikut :

- Media pembelajaran dapat memperjelas penyajian pesan dan informasi sehingga dapat memperlancar dan meningkatkan proses dan hasil belajar.

- Media pembelajaran dapat meningkatkan dan mengarahkan perhatian anak sehingga dapat menimbulkan motivasi belajar, interaksi yang lebih langsung antara siswa dan lingkungannya, dan kemungkinan siswa untuk belajar sendiri-sendiri sesuai dengan kemampuan dan minatnya.

- Media pembelajaran dapat mengatasi keterbatasan indera, ruang dan waktu.

- Media pembelajaran dapat memberikan kesamaan pengalaman kepada siswa tentang peristiwa-peristiwa di lingkungan mereka, serta memungkinkan terjadinya interaksi langsung dengan guru, masyarakat, dan lingkungannya misalnya melalui karya wisata. Kunjungan-kunjungan ke museum atau kebun binatang.

Media Pembelajaran banyak sekali jenis dan macamnya. Mulai yang paling kecil sederhana dan murah hingga media yang canggih dan mahal harganya. Ada media yang dapat dibuat oleh guru sendiri, ada media yang diproduksi pabrik. Ada media yang sudah tersedia di lingkungan yang langsung dapat kita manfaatkan, ada pula media yang secara khusus sengaja dirancang untuk keperluan pembelajaran. Meskipun media banyak ragamnya, namun kenyataannya tidak banyak jenis media yang biasa digunakan oleh guru di sekolah. Beberapa media yang paling akrab dan hampir semua sekolah memanfaatkan adalah media cetak (buku). selain itu banyak juga sekolah yang telah memanfaatkan jenis media lain gambar, model, dan Overhead Projector (OHP) dan obyekobyek nyata. Sedangkan media lain seperti kaset audio, video, VCD, slide (film bingkai), program pembelajaran komputer masih jarang digunakan meskipun sebenarnya sudah tidak asing lagi bagi sebagian besar guru.

\section{Metode Penelitian}

Metode yang di gunakan dalam penelitian ini adalah deskriftif analitik melalui tindakan, yaitu studi yang di gunakan untuk mengumpulkan data, mendeskritifkan, mengolah, menganalisa, dan menyimpulkan data sehingga memperoleh gambaran yang sistematis. Penelitian ini dilaksanakan di PAUD yang ada di lingkungan Kecamatan Padalarang Kabupaten Bandung Barat semester ganjil tahun pelajaran 2015-2016. Penelitian ini dilaksanakan pada bulan Juli sampai dengan Desember 2015. Materi pembahasan yang dikaji dalam penelitian tindakan ini yaitu pembuatan media pembelajaran. Penelitian ini dilaksanakan dalam 2 siklus, setiap siklus terdiri dari 2 pertemuan pelaksanaan workshop.

Penelitian ini dibagi dalam 2 siklus yang disesuaikan dengan alokasi waktu dan topik yang dipilih. Masing-masing siklus terdiri dari 4 langkah 
(Kemmis dan MC Taggart,1988) sebagaik berikut; a) perencanaan, yaitu merumuskan masalah, menentukan tujuan, dan metode-metode penelitian serta membuat rencana tindakan, (b) tindakan yang dilakukan sebagai upaya perubahan yang dilakukan, (c) observasi, dilakukan secara sistematis untuk mengamati sistem yang dapak tidakan terhadap proses belajar mengajar, dan (d) refleksi, yaitu mengkaji dan mempertimbangkan hasil atau dampak tindakan yang dilakukan.

Inrtumen yang digunakan dalam penelitian ini lembar observasi, lembar penilaian praktek digunakan untuk mengetahui kemampuan guru dalam pembuatan dan penggunanaan media. Setelah data terkumpul dan diperiksa, bila memenuhi persaratan maka data tersebut ditabulasikan dalam tabel yang siap untuk pengolahan, setelah dicek kebenarannya, kemudian di hitung persentasenya.

\section{HASIL PENELITIAN PEMBAHASAN}

DAN

Dari hasil penelitian dengan melaksanakan workshop pembuatan media, kemudian penulis menganalisis apakah pelaksanaan workshop pembuatan media tersebut dapat meningkatkan kemampuan guru dalam menggunakan media pembelajaran di Kecamatan Padalarang Kabupaten Bandung Barat. Berikut ini adalah data yang diperoleh dari hasil siklus pertama dan siklus ke dua.

Berdasarkan hasil penelitian selama dua siklus yang bertujuan untuk meningkatkan kemampuan guru dalam menggunakan media pembelajaran di Kecamatan Padalarang Kabupaten Bandung Barat, terlihat pada pelaksanaan siklus pertama dan ke dua telah menunjukkan bahwa dengan diterapkannya workshop pembuatan media kunjungn kelas, guru telah menggunakan media pembelajaran yang lebih menarik perhatian anak. Selain itu ketika menggunakan media, guru telah banyak melibatkan anak dalam pembelajaran. Kemudian peneliti melakukan workshop pembuatan media terhadap guru. Pada akhir kegiatan, peneliti mengevaluasi kegiatan. Berdasarkan hal tersebut, dapat disimpulkan bahwa telah ada peningkatan kemampuan guru dalam menggunakan media pembelajaran di Kecamatan Padalarang Kabupaten Bandung Barat. Hal ini dapat dilihat dari peningkatan rata-rata nilai workshop pembuatan media siklus 1 dan siklus ke 2 yang tersaji pada grafik 4.6 berikut.
Pelaksanaan workshop pembuatan media akademik ini dapat meningkatkan kemampuan guru dalam menggunakan media pembelajaran karena dengan adanya workshop pembuatan media ini guru menjadi termotivasi untuk menggunakan berbagai media pembelajaran yang dapat menunjang keberhasilan anak dalam belajar.

Peningkatan pemanfaatan media pembelajaran yang signifikan antara sebelum dan sesudah dilaksanakannya workshop pembuatan media juga disebabkan karena dengan workshop pembuatan media, para guru memahami arti penting sebuah media dalam pembelajaran. Hal tersebut membuat guru memilih dan menggunakan media pembelajaran dengan lebih baik lagi.

\section{KESIMPULAN}

1. Workshop pembuatan media dapat meningkatkan kemampuan guru dalam menggunakan media pembelajaran.

2. Proses peningkatan kemampuan guru ditandai dengan meningkatnya motivasi mereka untuk melakukan perbaikan dalam pembelajaran. Hal ini sangat terlihat dalam pelaksanaan kegiatan workshop dimana guru lebih antusias dalam memahami materi workshop dan juga saat simulasi dan praktek pembuatan media pembelajaran.

3. Besarnya peningkatan kemampuan guru dalam menggunakan media pembelajaran setelah diterapkan workshop pembuatan media pada siklus I mempunyai nilai rata-rata 70 dengan perbandingan $0 \%$ berada pada kategori baik, $70 \%$ berada pada kategori cukup dan 30\% berada pada kategori kurang. Pada siklus II, rata-rata kemampuan guru dalam menggunakan media pembelajaran meningkat menjadi 86,67, dengan perbandingan $100 \%$ berada pada kategori baik dan tidak ada yang berada pada pada kategori cukup dan kategori kurang

Dengan melihat hasil berdasarkan kajian teoritis dan temuan hasil penelitian yang diperoleh, maka peneliti menyarankan sebagai berikut :

1) Variasi kegiatan diperlukan oleh kepala sekolah untuk meningkatkan kemampuan guru dalam menggunakan media pembelajaran. Salah satunya mencoba menerapkan workshop pembuatan media.

2) Perlu diadakannya sosialisasi workshop pembuatan media agar para kepala sekolah dan guru bisa memahami dan dapat menerapkan secara baik di lapangan. 


\section{DAFTAR PUSTAKA}

Azhar Arsyad. 2000. Media Pengajaran. Jakarta: Raja Grafindo Persada

Akib, Zainal (2009). Pengembangan Profesi Guru dan Pengawas Sekolah dengan Penelitian Tindakan Kelas/Sekolah. Bandung: Yrama Widia

Hamalik, Oemar. 1999. Proses Belajar Mengajar. Jakarta: Bumi Aksara.

Mulyasa, Endang. (2009). Penelitian Tindakan Sekolah. Bandung: PT. Remaja Rosdakarya

Rustaman, Nuryani Y. Strategi Belajar Mengajar. Diktat Mata Kuliah. Universitas Pendidikan Indonesia. Tidak Diterbitkan.

Sumiati, dkk. 2009. Metode

Pembelajaran. Bandung : CV Wahana Prima.

Sundayana, Rustina. 2013. Media Pembelajaran Matematika (untuk guru, calon guru, orangtua, dan para pecinta matematika). Bandung : ALFABETA

Suwantikno, Tikky. (2007). Supervisi Guru. Tidak Diterbitkan.

Ismail. Andang. (2006). Education Games Menjadi Cerdas dan Ceria dengan Permainan Edukatif. Yogyakarta: Pilar Media.

Jamaris, M (2004). Assesmen Pendidikan Anak Usia Dini, Seminar dan Lokakarya Nasional Pendidikan Anak Usia Dini di Jakarta.

Kwartolo. Yuli. (2005). Jurnal Pendidikan Penabur - No.04 / Th.IV / Juli 2005 Sumber intrapersonal ways of knowing (Adapted by Leslie Wesman from the work of Howard Gardner, Thomas Armstrong. Linda Campbell, and David Lazear.

Lwin, M. at.all. (2008). Cara Mengembangkan Berbagai Komponen Kecerdasan. Alih bahasa: Christiane Sujana. Jakarta: Indeks.

M. Husna. (2009) Permainan Tradisional Indonesia Untuk Ketangkasan, dan Keakraban Sesuai untuk Edukasi, Training, dan Outbond. Yogyakarta: ANDI.

Musfiroh, Tadkiroatun. (2011). Pengembangan Kecerdasan Majemuk. Jakarta: Universitas Terbuka. 